\title{
United Kingdom Patent Decisions 2020
}

\author{
Robyn Trigg
}

Published online: 1 March 2021

(C) The Author(s) 2021

\begin{abstract}
This report highlights a selection of the most important UK patent decisions from 2020, including: two Supreme Court judgments (one concerning insufficiency and one concerning FRAND); two Court of Appeal judgments (considering SPC fees and Arrow declarations); and four High Court judgments (regarding the Crown use exception, injunctions and the public interest, the treatment of experts in patents trials and technical primers, and interim injunctions).
\end{abstract}

Keywords Arrow declarations - Crown use - Experts · FRAND · Injunctions · Insufficiency $\cdot$ SPC fees $\cdot$ Technical primers

Cases Actavis Group PTC EHF and others v. ICOS Corporation and another [2019] UKSC 15, [2020] 1 All ER 213; Akebia Therapeutics Inc v. Fibrogen Inc [2020] EWHC 866 (Pat), [2020] 4 WLUK 194; American Cyanamid Co v. Ethicon Ltd [1975] AC 396; Arrow v. Merck [2007] EWHC 1900 (Pat), [2008] Bus LR 487; C-170/13 Huawei Technologies Co Ltd v. ZTE Corp, ZTE Deutschland GmbH [2015] OJ C 302; Conversant Wireless Licensing SARL v. Huawei Technologies Co Ltd [2018] EWHC 808 (Pat), [2018] 4 WLUK 187; Conversant Wireless Licensing SARL v. Huawei Technologies Co Ltd \& ZTE Corp [2019] EWCA Civ 38, [2019] 1 WLUK 278; Edwards Lifesciences v. Boston Scientific [2018] EWHC 1256 (Pat), [2018] 5 WLUK 459; Edwards Lifesciences v. Meril [2020] EWHC 2562, [2020] 9 WLUK 326; Evalve Inc and Ors v. Edwards Lifesciences Ltd [2020] EWHC 513 (Pat), [2020] 3 WLUK 196; Evalve Inc and Ors v. Edwards Lifesciences Ltd [2020] EWHC 514 (Pat), [2020] 3 WLUK 205; Genentech Inc v. Comptroller General of Patents [2020] EWCA

\footnotetext{
R. Trigg $(\bowtie)$

DPhil Candidate; Magdalen College, University of Oxford, and Solicitor (England and Wales), Oxford, UK

e-mail: robyn.trigg@magd.ox.ac.uk
} 
Civ 475, [2020] Bus LR 1774; Honeywell International Inc v. Mexichem UK Ltd [2020] EWCA Civ 473, [2020] 3 WLUK 476; IPCom GmbH \& Co KG v. Vodafone Group Plc [2020] EWHC 132 (Pat), [2020] Bus LR 514; IPCOM GmbH and Co KG v. HTC Europe Co Ltd [2015] EWHC 1034 (Pat), [2015] 4 WLUK 511; IPCOM GmbH and Co KG v. HTC Europe Co Ltd [2017] EWCA Civ 90, [2017] 2 WLUK 714; MedImmune Ltd v. Novartis Pharmaceuticals UK Ltd [2011] EWHC 1669 (Pat), [2011] 7 WLUK 92; Merck Sharp and Dohme Ltdv. Shionogi \& Co Ltd [2016] EWHC 2989 (Pat), [2016] 11 WLUK 667; Mexichem UK Ltd v. Honeywell International Inc [2019] EWHC 3377 (Pat), [2019] 11 WLUK 581; Nokia Oyj (Nokia Corp) v. IPCom GmbH \& Co KG [2011] EWHC 1470 (Pat), [2011] 6 WLUK 355; Nokia Oyj (Nokia Corp) v. IPCom GmbH \& Co KG [2012] EWCA Civ 567, [2012] 5 WLUK 341; Neurim Pharmaceuticals (1991) Ltd v. Generics UK Ltd (t/a Mylan) [2020] EWHC 3270 (Pat), [2020] 12 WLUK 84; Neurim Pharmaceuticals (1991) Ltd v. Generics UK (t/a Mylan) [2020] EWHC 1362 (Pat), [2020] 6 WLUK 23; Pfizer Ltd v. F HoffmannLa Roche AG [2019] EWHC 1520 (Pat), [2019] 6 WLUK 324; Regeneron Pharmaceuticals Inc v. Kymab Ltd [2016] EWHC 87 (Pat), [2016] 2 WLUK 13; Regeneron Pharmaceuticals Inc v. Kymab Ltd [2018] EWCA Civ 671, [2018] 3 WLUK 685; Regeneron Pharmaceuticals Inc v. Kymab Ltd [2020] UKSC 27, [2020] Bus LR 1394; Technograph Printed Circuits Limited v. Mills \& Rockley (Electronics) Ltd [1972] RPC 346; Unwired Planet International Ltd v. Huawei Technologies Co Ltd [2017] EWHC 711 (Pat), [2017] 4 WLUK 74; Unwired Planet International Ltd $v$. Huawei Technologies (UK) Co Ltd [2018] EWCA Civ 2344, [2018] 10 WLUK 355; Unwired Planet International Ltd v. Huawei Technologies (UK) Co Ltd [2020] UKSC 37, [2020] Bus LR 2422

\section{Legislation Patents Act 1977, Patent Rules 2007}

Notwithstanding this being a globally unprecedented year, the world of patents in England and Wales has remained active. With ever changing public health restrictions, the courts have had to adapt to new ways of working, utilising technology to conduct sessions entirely remotely or in a hybrid format. ${ }^{1}$ Despite the challenges 2020 has presented, we have still seen numerous patent decisions from the Supreme Court, the Court of Appeal, and the High Court - too many to cover them all thoroughly here. This review will give an outline of some of the most important patent decisions in 2020.

\section{IPCom GmbH \& Co KG v. Vodafone Group Plc}

The year started off with some standard essential patent (SEP) litigation - a technical trial in a FRAND dispute. ${ }^{2}$ IPCom's patent at issue in this litigation is a

\footnotetext{
1 See comments from Birss J (as he then was) in Edwards Lifesciences v. Meril [2020] EWHC 2562; [2020] 9 WLUK 326 at [9]-[10] where he discusses the "hybrid" hearing format used in that trial whereby the trial was conducted in person in a limited fashion and remotely via an audio/video system. Birss J noted the Patents Court's history of working flexibly by video conferencing stating that "[i]t promotes access to justice and is often necessary for a fair trial ..." [10].

${ }^{2}$ IPCom GmbH \& Co KG v. Vodafone Group Plc [2020] EWHC 132 (Pat); [2020] Bus LR 154.
} 
family member of another patent litigated previously by IPCom against Nokia and HTC. ${ }^{3}$ However, the other family member was litigated in the context of the $3 \mathrm{G}$ network, rather than $4 \mathrm{G}$ as in this case, and against handset providers, rather than a network infrastructure provider as in this case. ${ }^{4}$

IPCom's patent in issue here relates to a method for allocating mobile devices access rights to particular telecommunications channels at particular times. ${ }^{5}$ The claimed method allows for differentiation between devices based on the type of enduser. All mobile devices receive a class number from their SIM card. Ordinary consumer devices randomly receive a class number between 0-9; however, there are further specialised classes (11-15) and each of these classes contains the mobile devices of a certain group of end-users. For example, class 14 is only comprised of mobile devices belonging to the emergency services.

IPCom's claimed method allows the network to differentiate between devices in the ordinary class numbers (0-9) and those in the specialised classes (11-15) by sending out an access class bit which corresponds to the relevant class number. ${ }^{6}$ On the basis of this differentiation, base stations can then authorise only devices belonging to a particular class immediate access to a particular channel. This would result in priority access without undergoing the "lottery" which ordinarily takes place to determine channel access. ${ }^{7}$

This could be used particularly for prioritising devices belonging to the emergency services. In fact, the UK Government created the Mobile Telecommunications Privileged Access Scheme (MTPAS) for the prioritisation of devices belonging to the emergency services in emergency situations. As per MTPAS, a senior police officer can request that mobile network providers give emergency responders priority network access. ${ }^{8}$

There were a number of issues at play in this litigation and also parallel opposition proceedings at the European Patent Office (EPO). As a result of a preliminary opinion in 2019 from the EPO Opposition Division, IPCom filed an application for unconditional amendments to the claims as granted under section 75 Patents Act 1977 (PA 1977) (referred to as the "unconditionally amended claims"). IPCom later also filed another application to make amendments under section 75 PA 1977 in the event that the first application failed (these were referred to as the “conditionally amended claims"). ${ }^{9}$ Thus, Recorder Douglas Campbell QC had to decide: (i) the construction and allowability of both the unconditionally and conditionally amended claims; (ii) obviousness in light of the prior art; (iii) the

\footnotetext{
3 See Nokia Oyj (Nokia Corp) v. IPCom GmbH \& Co KG [2011] EWHC 1470 (Pat), [2011] 6 WLUK 355; Nokia Oyj (Nokia Corp) v. IPCom GmbH \& Co KG [2012] EWCA Civ 567, [2012] 5 WLUK 341; IPCOM GmbH and Co KG v. HTC Europe Co Ltd [2015] EWHC 1034 (Pat), [2015] 4 WLUK 511; IPCOM GmbH and Co KG v. HTC Europe Co Ltd [2017] EWCA Civ 90, [2017] 2 WLUK 714.

4 Supra note 2, [3].

5 Supra note 2, [1].

6 Supra note 2, [43] et seq.

7 Supra note 2, [47].

8 Supra note 2, [207].

9 Supra note 2, [7].
} 
essentiality of both sets of claims; (iv) Vodafone's arguments of non-infringement, including the rarely used Crown use defence and a de minimus defence; and (v) Vodafone's counterclaim for declarations of non-infringement. ${ }^{10}$

Ultimately, Recorder Douglas Campbell QC found IPCom's patent (in amended form) to be valid, essential, and infringed. ${ }^{11}$ What was interesting about the case was Vodafone's successful use of the little utilised Crown use defence. ${ }^{12}$ Vodafone successfully claimed that its use of the patented method for controlling network access when responding to requests via MTPAS was covered by the defence of Crown use.

Section 55 PA 1977 sets out the Crown use defence. There is a defence to patent infringement without consent when a government department or a person authorised in writing by a government department infringes a patent for the purposes of services to the Crown. Sections 55(4) and 57A PA 1977 make provision for compensation, section 56 PA 1977 contains provisions of interpretation, and section 59 makes special provision for Crown use during emergencies. ${ }^{13}$

Section 56(2) PA 1977 sets out a list of three scenarios included within the concept of Crown use: (a) the supply of anything for foreign defence purposes; (b) the production or supply of specified drugs and medicines; and (c) the production of, use of, or research into atomic energy. Section 59 PA 1977 sets out a further list of what constitutes Crown use in an emergency.

In addition to the points made at trial by the parties on this defence, the Judge also received written submissions from the Comptroller given that the Crown use defence concerns a point of public interest. These submissions were received after the Recorder had released a draft judgment to the parties. In light of the Comptroller's submissions, the parties submitted further written submissions and Recorder Douglas Campbell QC amended this part of his draft judgment. ${ }^{14}$

There was agreement between the parties that Vodafone had written authorisation from a government department to make use of the claimed method in providing priority access to its network to emergency services under the MTPAS. ${ }^{15}$ However, dispute arose over the following points: (i) did the use of the claimed method in response to an MTPAS request fall within the scope of Crown use?; ${ }^{16}$ (ii) did authorisation to do a specific act imply an authorisation to infringe a patent not specifically mentioned in that authorisation?; ${ }^{17}$ and (iii) was testing or keeping the equipment necessary to respond to a MTPAS request itself infringing IPCom's

\footnotetext{
${ }^{10}$ Supra note 2, [9].

11 On construction, see supra note 2, [69]-[93]; on added matter see supra note 2, [95]-[123]; on obviousness over the prior art see supra note 2, [124]-[141]; on essentiality see supra note 2, [142][180]; on infringement see supra note 2, [181]-[242]; on Vodafone's application for declarations of noninfringement see supra note 2, [243]-[248]; and for conclusion see supra note 2, [249].

12 Sections 55-59 PA 1977.

13 Supra note 2, [184] et seq.

14 Supra note 2, [185].

15 Supra note 2, [191].

16 Supra note 2, [187]-[189].

17 Supra note 2, [191] et seq.
} 
patent, separate to whether the use of that equipment to respond to an MTPAS request was covered by the Crown use defence? ${ }^{18}$

As to point (i), the Recorder concluded that Vodafone's use of the claimed method in responding to MTPAS requests does fall within the scope of Crown use. IPCom had contended that the three circumstances listed in section 56(2) PA 1977 were exhaustive and, in any event, Vodafone's use fell outside of the scope of "for the services of the Crown". Vodafone and the Comptroller, however, had argued that the inclusion of the word "including" prior to listing these scenarios in the provision indicated that the list was non-exhaustive. The Recorder agreed with Vodafone and the Comptroller concluding "[w] hatever the precise limits of section 56(2), I am satisfied that this constitutes use 'for the services of the Crown'."19

With respect to point (ii), the Recorder concluded that the fact that MTPAS does not specifically state that the patent in issue can be infringed, or indeed any patent in particular, and that it also does not state the particular use of the LTE network to meet an MTPAS request, is not a bar to the Crown use defence being used. ${ }^{20}$ Recorder Douglas Campbell QC stated that what is important is the written authorisation to do the relevant act (i.e. respond to MTPAS requests). Vodafone did not need to demonstrate that it was necessary to infringe the patent to carry out the relevant act. $^{21}$

Lastly, concerning point (iii), the Recorder favoured Vodafone's argument that in order to be able to properly respond to a MTPAS request when received, it needed to be able to test its own ability to do so. Thus, the Crown use defence extended to any infringement carried out by virtue of testing the equipment. Furthermore, the Judge stated that the defence would also apply to any infringement arising out of keeping the equipment necessary to fulfil the MTPAS request for as long as the MTPAS is in operation. ${ }^{22}$

The Crown use defence is rarely used in patent cases and, despite its successful deployment by Vodafone here, it remains to be seen whether we will see this defence being used more frequently in telecoms patent litigation. However, with an increase in FRAND litigation in the telecoms space, we may see parties seeking to repeat Vodafone's success with the defence.

\section{Evalve Inc and Ors v. Edwards Lifesciences Ltd}

Later, in March 2020, Birss J (as he then was) delivered two judgments in the litigation between Evalve and Edwards Lifesciences. ${ }^{23,24}$ One judgment dealt with two of Evalve's patents concerning devices used to treat mitral valve regurgitation

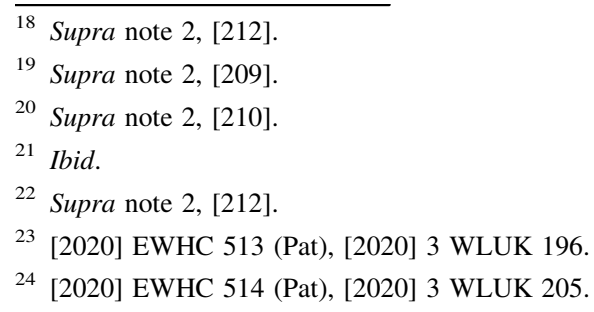


by transcatheter technique. Both patents were held to be valid and infringed by Edwards' PASCAL device. ${ }^{25}$

The second judgment, which shall be the focus here, concerned what the parties called the "public interest trial". ${ }^{26}$ The issue to be decided in this judgment was, per Edwards' submission, even if the PASCAL product infringed one of Evalve's patents, whether a final injunction should be ordered on the basis that it would be contrary to the public interest. ${ }^{27}$

The patents in issue protect a successful product called the MitraClip. Prior to the MitraClip there were no effective transcatheter treatments available for mitral valve regurgitation and the only option was open heart surgery. Incidence of mitral valve regurgitation increases with age but many older patients are not suitable for open heart surgery. However, without treatment many patients with progressive mitral valve regurgitation will die within a year of diagnosis. Thus, being able to treat the condition by transcatheter technique is significantly important. ${ }^{28}$

There are two kinds of MitraClip on the market today. The PASCAL product is another transcatheter treatment option and operates in much the same way as the MitraClip. Per Birss J's (as he then was) first judgment, the PASCAL product was found to infringe Evalve's patents. As a result of this infringement, Evalve sought a final injunction under section 61(1)(a) PA 1977 to prohibit Edwards from marketing the PASCAL product. ${ }^{29}$

Edwards, however, argued that no such injunction should be issued, or if one is granted then it should contain certain exemptions covering specific clinical scenarios, because the availability of the PASCAL device serves the public interest. Edwards argued that the public interest is served because, at least with respect to certain patients, a reasonable doctor would opt for the PASCAL device over the MitraClip as it would be a better device to use. And, thus, it would not be in the public interest to prevent doctors from making this choice. ${ }^{30}$

In reaching his decision, the Judge considered the law relating to injunctions generally and in the context of patents specifically. He ultimately concluded that there are seven principles which apply when a party is seeking to prevent the grant of a final injunction on the basis of public interest: (i) a general injunction to prevent future infringement is the normal remedy for a patentee; (ii) the burden rests with the defendant to give reasons why an injunction should not be granted; (iii) all circumstance should be considered in the decision of whether an injunction should be granted and the public interest (such as the impact on third parties) is a relevant consideration; (iv) in an appropriate case the public interest may justify refusal of or carve out from an injunction, and instead an award of damages in lieu may be made; (v) the starting point of considering the public interest in relation to a remedy is "that the patent system as a whole is already criss-crossed with provisions which

\footnotetext{
25 Ibid.

26 Supra note 23, [1].

27 Ibid.

28 Supra note 23, [2].

29 Supra note 23, [32].

30 Supra note 23, [5].
} 
strike balances between different public interests"; (vi) the availability of an exclusionary injunction is a necessary part of the patent system as a whole and monopolistic patent rights; and (vii) the power to "redraw the broad balance of public interests set by Parliament in the patent system" should be used "sparingly and in limited circumstances" - the legislator is better equipped to deal with the various pulls of different public interests. ${ }^{31}$

In considering these points, the Judge concluded that the injunction would be granted on the terms sought by Evalve. Namely, that the only carve out from the injunction would be for patients for whom the MitraClip had been unsuccessful. ${ }^{32}$ The Judge had used the decision of Arnold $\mathbf{J}$ (as he then was) in Edwards Lifesciences $v$. Boston Scientific ${ }^{33}$ as the starting point in considering when the question of public interest arises and concluded that the matter of public interest arises in cases "concerned with treatment for serious medical conditions, and perhaps only for life saving treatments". ${ }^{34}$ The preference of a notional doctor or class of doctors to use one treatment over another is not sufficient to prevent an injunction being granted or to ground caveats to that injunction. ${ }^{35}$ Thus, what is necessary is evidence to show that there are patients who could not be treated by the patented treatment but could be treated by the rival treatment.

On reviewing the relevant clinical data, the Judge concluded that " $[\mathrm{t}]$ here is no reliable clinical data which identifies any class of patients for which it is more likely than not that PASCAL is the only viable treatment". ${ }^{36}$ As such, the injunction was broadly granted with the only carve out being for patients for whom the MitraClip had already been unsuccessful. This decision confirms again the high hurdle that must be overcome in order for matters of public interest to be a relevant consideration in preventing the grant of or limiting the scope of injunctions.

\section{Genentech Inc v. Comptroller General of Patents}

Next, the Court of Appeal considered two expedited appeals from the High Court $^{37,38}$ concerning an error in the payment of fees for Genentech's SPC for the product Lucentis. The High Court had held that the error could not be subsequently corrected and the duration of the SPC could not be extended to the maximum duration.

The two relevant appeals were from Genentech itself and from Master Data Centre Inc. (MDC), who acted as Genentech's agent in connection with paying the SPC fees. Genentech had instructed MDC to apply for an SPC for its product

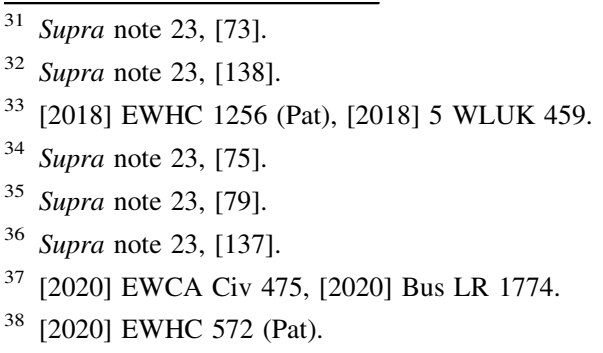


Lucentis for the maximum duration (which would have expired in 2022), but MDC only applied for a two-year SPC (which was due to expire in April 2020).

The Comptroller had originally been asked to grant a remedy which would have had the effect of allowing the SPC to continue until its maximum duration. The Comptroller refused to grant this remedy. This was appealed to the High Court but the appeals were rejected.

In the Court of Appeal appeal, MDC relied on Rule 107 of the Patent Rules 2007. This rule gives the Comptroller discretion to correct an "irregularity of procedure", if such an irregularity can be attributed to the Comptroller. MDC argued that there were three of these irregularities: (i) the notice given to MDC by the UKIPO failed to detail the prescribed fee due; (ii) the notice and form included erroneously suggested that the applicant could opt for a period of protection less than the maximum duration; and (iii) the Comptroller did not notify MDC of its failure to pay the prescribed fee.

In response to this appeal, Floyd LJ (with whom Arnold and Nicola Davies LJJ agreed) upheld the High Court decision rejecting the submission that the UK SPC scheme does not permit an applicant to opt and pay for a shorter period of protection than the maximum duration. ${ }^{39}$ Floyd listed the following points as "salient features" of the UK SPC scheme: (i) the prescribed fee is the total of specified annual fees (although it is payable as a lump sum in advance); (ii) the paying of a prescribed fee of an amount less than for the whole term allows the applicant to opt for an SPC with a shorter duration; (iii) applicants cannot pay top-up annual fees; and (iv) if the applicant opts for a shorter duration than the maximum, then the SPC lapses at the end of that shorter period. ${ }^{40}$

Genentech's appeal differed to MDC's. The three grounds of Genentech's appeal were: (i) on the proper construction of Rule 116(5) of the Patent Rules 2007, is an applicant for an SPC who has paid less than the full amount of fees at the outset entitled to pay a further fee to make up the shortfall if they apply for a paediatric extension of the SPC?; (ii) alternatively, does section 117 PA 1977 permit a correction to the relevant form so as to substitute the correct period for the SPC to take effect and the correct fee?; and (iii) in the further alternative, is a paediatric extension of six months from the current expiry (less than the maximum term) permissible ${ }^{41}$

Floyd LJ rejected all three of these grounds of appeal. As to the first ground, the Judge stated that if Genentech was entitled to a paediatric extension then the only consequence would be an extension by six months, it would not allow the original shortfall in fees to be corrected. ${ }^{42}$ Furthermore, Floyd LJ held that the paediatric extension should not interfere with his previous analysis with respect to MDC's appeal that paying a reduced fee allows an applicant to opt for a shorter duration. ${ }^{43}$ Thus, the only further fee that can be paid with respect to an SPC is for the paediatric extension itself. ${ }^{44}$

\footnotetext{
39 Supra note 37, [43].

40 Supra note 37, [42].

41 Supra note 37, [48].

42 Supra note 37, [50].

43 Supra note 37, [50]-[56].

44 Supra note 37, [56].
} 
As to the second ground of appeal, Floyd LJ held that the argument was not sufficient to rectify the mistake in the relevant form. He stated that further fees would also need to be paid to rectify the mistake but, as established, the paying of further fees is not permitted. ${ }^{45}$ Finally, with respect to the third ground, Floyd LJ rejected this by concluding that a paediatric extension is possible only as an extension to a maximum term SPC. ${ }^{46}$

This judgment underscores the importance of paying the correct fees. In order to receive an SPC for the maximum duration, the applicant must pay the total due fees in a lump sum in advance. Any errors in the fees paid cannot be rectified at a later date.

\section{Honeywell International Inc v. Mexichem UK Ltd}

We then received another Court of Appeal judgment, ${ }^{47}$ this time dealing with the extent and scope of a particular type of declaratory relief, Arrow declarations. ${ }^{48}$ The issue arose in action brought by Mexichem for the revocation of six patents owned by Honeywell. All six patents relate to compounds used in refrigeration systems, in particular two compounds known as "ze" and "yf". ${ }^{49}$ Mexichem wishes to be free to market "ze" and "yf" in the UK for use in mobile air-conditioning systems (MACs). In addition to these six patents, Mexichem is also concerned that Honeywell has at least four other divisional patents undergoing examination at the EPO. As such, Mexichem also sought declaratory relief in the form of an Arrow declaration establishing that the concept of using ze and yf compounds in MACs was obvious at particular dates, in order to protect itself from the potential impact of the grant of these ongoing applications. ${ }^{50}$

The six patents in suit have a priority date of either 25 October 2002 or 29 April 2004. By 25 October 2002 both ze and yf compounds were detailed in a Japanese patent application made available to the public, known as "Inagaki". Accordingly, Mexichem sought declaratory relief that by 25 October 2002 and/or 29 April 2004 it was obvious in light of the teaching of Inagaki "(a) to use ze in the manufacture of a product for use as a refrigerant in a MAC; and/or (b) to use yf in the manufacture of a product for use as a refrigerant in a MAC". 51

\footnotetext{
45 Supra note 37, [60].

46 Supra note 37, [65]-[67].

49 Supra note 47, [2].

50 Supra note 47, [3].

51 Supra note 47, [4].
}

47 Honeywell International Inc v. Mexichem UK Ltd [2020] EWCA Civ 473, [2020] 3 WLUK 476.

48 Taking its name from the case of Arrow v. Merck [2007] EWHC 1900 (Pat); [2008] Bus. L.R. 487, where this type of declaratory relief was first sought. An Arrow declaration is a declaration that a product or process was known or obvious at a certain date such that any patents after that date covering that product or process would necessarily be invalid. See the discussion on Arrow declarations with respect to the decision of Pfizer Ltd v. F Hoffmann-La Roche AG [2019] EWHC 1520 (Pat), [2019] 6 WLUK 324 in last year's patent review, IIC 51:341-361 (2020), doi:https://doi.org/10.1007/s40319-020-00913-2. 
Honeywell applied to strike out Mexichem's claim for this declaratory relief (or, alternatively, for summary judgment against Mexichem) on the basis that Mexichem had no real prospect of success in obtaining this relief at trial. Honeywell contended that the declaration sought by Mexichem was not sought in relation to a specific product or process which it intends to bring to market in the $\mathrm{UK}$, that it is not sufficiently clear, and that a declaration in such broad terms lacks utility. $^{52}$

At first instance, HHJ Hacon rejected Honeywell's claims that an Arrow declaration had to be sought in respect of a specific product or process but that more general declarations could also serve a useful purpose. As such, HHJ Hacon refused to strike out Mexichem's claims or give summary judgment. ${ }^{53}$

Honeywell appealed the first instance judgment arguing, inter alia, that HHJ Hacon had been wrong: (i) not to require any product or process to be identified; (ii) to find that a declaration in general terms might serve a useful purpose (because, Honeywell argued, there would be no resolution of the issue until a second round of contested proceedings); and (iii) to treat the question of inventive step as something that could be "sliced up" and treated in a stepwise fashion. ${ }^{54}$

Mexichem, on the other hand, supported HHJ Hacon's reasoning and maintained that the scope and generality of the declaration sought was "entirely appropriate given the breadth of the inventive concept which Honeywell was endeavouring to protect". It sought to make this point by examining the claims of the patents in suit and by pointing to proceedings brought by Honeywell in Germany where it argued it was implicit that Honeywell was claiming that it was entitled to a monopoly in the broad concept of using ze and yf in MACs. ${ }^{55}$

In considering these issues, Floyd LJ (with whom Lewison LJ agreed) concluded that in order to apply for an Arrow declaration, it is not necessary for an applicant to have a "fully formulated product description, far less that it must have a product in actual production". 56 He stated that what must be established is that "it would be useful for specified features of a product which the party wishes to sell to be declared old or obvious". Further, it is enough at the strike out or summary judgment stage for a party to show that there is "a real prospect of its being able to establish those matters at trial". 57

As to Honeywell's point that the grant of broad declarations might lead the court into a stepwise analysis of obviousness, Floyd LJ concluded that whilst the stepwise analysis of obviousness has been held to be unfair in many cases,${ }^{58}$ there are a class of cases where it may be relevant to consider it in a stepwise fashion. ${ }^{59}$ Floyd LJ

\footnotetext{
52 Supra note 47, [5].

53 Mexichem UK Ltd v. Honeywell International Inc [2019] EWHC 3377 (Pat); [2019] 11 WLUK 581 at [23]-[25].

54 Supra note 47, [9].

55 Supra note 47, [12].

56 Supra note 47, [18].

57 Supra note 47, [18].

58 See Technograph Printed Circuits Limited v. Mills \& Rockley (Electronics) Ltd [1972] RPC 346.

59 Supra note 47, [23] et seq.
} 
pointed to Lord Hodge in Actavis Group PTC EHF and others v. ICOS Corporation and another" ${ }^{60}$ who said " $[\mathrm{w}]$ here the pattern of the research programme which the notional skilled person would undertake can clearly be foreseen, it may be legitimate to take a step by step analysis" and in this case "the steps which the notional skilled person would take can readily be ascertained without the taint of hindsight". ${ }^{61}$ Thus, Floyd LJ held that "it is at least open to Mexichem to argue that a declaration about the step of deciding to use ze and yf for this purpose [deciding to use ze or yf as a refrigerant in MACs] would serve a useful purpose". ${ }^{62}$

Moreover, Floyd LJ held that Mexichem should be able to seek a broad declaration at trial because it is possible that Honeywell is seeking to protect an inventive concept which is similarly broad, such that it would not even be necessary to consider obviousness in a stepwise manner. ${ }^{63}$ Such a broad declaration would therefore have utility in addressing claims with corresponding scope.

Floyd LJ ultimately rejected Honeywell's appeal, finding that HHJ Hacon had been "fully justified" in refusing to strike out or give summary judgment on Mexichem's claim for declaratory relief. Thus, whilst this case helps solidify the circumstances in which Arrow declarations can be sought and the breadth of the scope that can be sought, it remains to be seen whether Mexichem will be successful in obtaining relief in the form sought. What is clear, though, is that Arrow declarations can be sought in broad terms and they need not be limited to a specific product or process in order to be deemed to be capable of serving a useful purpose.

\section{Akebia Therapeutics Inc v. Fibrogen Inc}

Next, we had a judgment from Arnold LJ (sitting as a High Court judge) in a case where Akebia and Otsuka Pharmaceutical Co Ltd were seeking to revoke six of Fibrogen's patents, concerning the use of inhibitors of an enzyme used for treating anaemia and related conditions, in order to clear the way for their product vadadusat. ${ }^{64}$ Subsequently, the exclusive licensee of the patents, Astellas Pharma Inc, also brought a cross-claim for threatened infringement. This was a characteristically comprehensive judgment from Arnold LJ, which covered issues including obviousness, ${ }^{65}$ insufficiency, ${ }^{66}$ claim construction, ${ }^{67}$ and infringement by equivalence. ${ }^{68}$ In addition, there were also useful comments concerning the use of experts and technical primers in patent cases - this shall be the focus of this summary.

\footnotetext{
${ }^{60}$ [2019] UKSC 15, [2020] 1 All ER 213 at [72]; see IIC 50:1012-1013(2019), doi:https://doi.org/10. 1007/s40319-019-00865-2.

61 Supra note 47, [23].

62 Supra note 47, [24].

63 Supra note 47, [25].

64 Akebia Therapeutics Inc v. Fibrogen Inc [2020] EWHC 866 (Pat), [2020] 4 WLUK 194.

65 Supra note 64, see for example [304]-[346] and [554]-[574].

66 Supra note 64, see for example [348]-[405] and [575]-[578].

67 Supra note 64, see for example [259]-[303] and [549]-[553].

68 Supra note 64, see for example [412]-[462].
} 
Taking the issue of the use of experts first. Arnold LJ considered it necessary to address the use of experts in patent cases and revisited previous decisions where he had touched upon the same. Arnold LJ noted that the Patents Court "depends on the assistance it receives from expert witnesses", particularly in complex cases such as this one. He acknowledged that preparing expert reports and giving oral evidence can be "arduous" but that it is "vital" that the task is not made more difficult by the lawyers involved. ${ }^{69}$

Arnold LJ then reiterated the statement he made in MedImmune Ltd v. Novartis Pharmaceuticals $U K \mathrm{Ltd}^{70}$ which emphasised that the lawyers who instruct expert witnesses have a "heavy responsibility" for ensuring that expert witnesses do not get into the position where they are made to appear to have failed in their duty to the court when they believe they have complied with that duty. ${ }^{71}$ Arnold LJ then reemphasised the key point he had made in Merck Sharp and Dohme Ltd v. Shionogi \& Co $\mathrm{Ltd}^{72}$ that "too much time is spent by cross-examiners in patent cases on $\mathrm{ad}$ hominem attacks that are unfair to the witness, unhelpful to the court and waste expensive time". 73

Despite these previous warnings on the use of experts in patent cases, Arnold LJ stated that these warning were "not being sufficiently heeded". He noted that the nephrology experts in this case had been "let down" by their instructing lawyers and one was cross-examined "unfairly". He further warned that this was unacceptable and a matter of professional responsibility. Underscoring this with another warning, "[i]f practitioners continue not to observe the standards required of them, the Patent Court will have to take steps to enforce those standards". ${ }^{7}$

Moreover, Arnold LJ noted that this case illustrated why it is advantageous to instruct experts in sequence, i.e. using the procedure known as "sequential unmasking", despite there being no rule or principle mandating it. For example, sequential unmasking would involve first asking the expert about the common general knowledge, then showing them the prior art and asking what steps would be obvious in light of it, and then finally, once this is complete, showing them the patent in suit. This procedure aims to avoid, or reduce, hindsight. In this case, because of the arguments run and how the case developed over time, Arnold LJ acknowledged that "it would not have been possible to instruct him [Prof Haase] in a manner which was free from hindsight" but that it was necessary to take into account that he had seen the patent before formulating his views on some of the obviousness arguments. ${ }^{75}$

Moving on to the issue of technical primers. Arnold LJ stated that it was regrettable that there was no technical primer in this case. There had been a disagreement as to whether one was needed and that at the case management

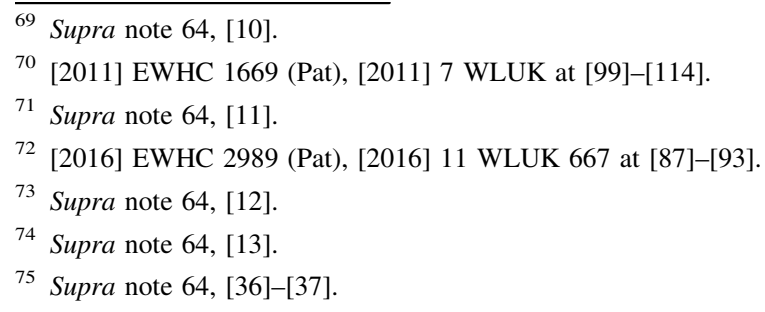


conference the judge had not ordered one. Arnold LJ noted that with hindsight this was a mistake and the preparation of a primer at an early stage would have "saved considerable time and effort". With this in mind, Arnold LJ stated that a technical primer should be considered "mandatory" in all Category 4 and 5 patent cases "unless there are good reasons to the contrary". 76

This case underscores the importance of the sequential unmasking approach in preparing expert witnesses and reminds the instructing lawyers to consider their conduct and professional responsibilities. It also highlights the important role technical primers play in allowing the court to understand complex cases.

\section{Neurim Pharmaceuticals (1991) Ltd v. Generics UK (t/a Mylan)}

This next case was an interim hearing wherein Marcus Smith J refused to grant an application for an interim injunction (pending final judgment) on the basis that damages would be an adequate remedy. ${ }^{77}$ This case involved Neurim's patent claiming prolonged release pharmaceutical formulation of melatonin to improve the restorative quality of sleep in patients suffering primary insomnia characterised by non-restorative sleep. ${ }^{78}$ The claimed formulation is sold under the brand name Circadin and the paediatric version of the formulation is sold under the brand name Slenyto. Importantly, the patent was due to expire in August 2022, with Mylan proposing a "fairly imminent" release of a generic rival to Circadin. ${ }^{79}$

Neurim (and the exclusive licensee under the patent, Flynn) launched these proceedings and contended that Mylan intends to infringe the patent in issue and they seek a declaration of infringement and injunctive and other relief. Mylan counterclaimed for revocation of the patent on grounds of anticipation, obviousness, and insufficiency. ${ }^{80}$

This hearing was concerned with whether interim injunctive relief should be provided until after the final judgment in these proceedings. In considering whether to grant an interim injunction, Marcus Smith J first started with the classic test set out by Lord Diplock in American Cyanamid Co v. Ethicon Ltd. ${ }^{81}$ The American Cyanamid test is broadly as follows: (i) is there a serious question to be tried?; (ii) is an award of damages an adequate remedy?; (iii) if damages are not adequate for the claimant, what is the adequacy of the undertaking in damages to the defendant?; and (iv) if there is no adequate remedy for either side, then the court must take into account all relevant factors (balance of convenience). ${ }^{82}$

\footnotetext{
76 Supra note 64, [48].

77 Neurim Pharmaceuticals (1991) Ltd v. Generics UK (t/a Mylan) [2020] EWHC 1362 (Pat), [2020] 6 WLUK 23.

78 Supra note 77, [2].

79 Supra note 77, [9].

80 Supra note 77, [11].

81 [1975] AC 396 at 406 et seq.

82 Supra note 77, [14].
} 
In pharmaceutical cases, it is fairly typical for interim injunctive relief to be granted, with damages being deemed to be inadequate to compensate for an irrecoverable drop in price caused by the first entrance of a generic on the market. Moving away from this somewhat typical outcome, Marcus Smith J applied the American Cyanamid test to the present case. As to (i), the Judge held that it was "difficult to see how it could be said that there was not serious issue to be tried as to the validity of the Patent". ${ }^{83}$ With respect to limb (ii), whether damages are an adequate remedy, the Judge concluded that they were.

Marcus Smith $\mathrm{J}$ held that it was possible to calculate the losses suffered by Neurim (and/or Flynn) even if that was an irrecoverable loss of their market position. ${ }^{84}$ The Judge also considered two special cases in his assessment of the adequacy of damages: (1) the entry of other competitors besides Mylan into the market place; ${ }^{85}$ and (2) what were termed "consequential effects" (e.g. the impact on $\mathrm{R} \& \mathrm{D}$, clinical trials, and manufacturing and distribution networks, etc.). ${ }^{86}$

As to (1) of the special cases considered, whilst the Judge did recognise that the entrance of other competitors into the marketplace would cause "additional complications to the damages claim", he eventually concluded that these additional complications were not enough to persuade him that damages were an inadequate remedy. ${ }^{87}$ As to (2) of the special cases, the Judge took into account the fact that Neurim was a company of "some substance" that "sits on cash of a significant amount" and would be able to fund these consequential effects in the interim. ${ }^{88} \mathrm{He}$ also noted that these consequential losses would arise in the near future anyway, on expiry of the patent in 2022. He stated that the consequence of him not granting the interim injunction would be to "cause these consequences to vest early and (assuming the Patent is indeed infringed) for the limited period of Period 1". As a result of this, the Judge concluded that the consequential losses inflicted would be recoverable as damages and, as Neurim (and Flynn) are able to fund those losses, damages were deemed to be an adequate remedy. ${ }^{89}$

Despite Neurim and Flynn failing the second stage of the American Cyanamid test, the Judge went on to consider the third and fourth limbs. As to the third limb, whether damages are an adequate remedy for the defendant, Marcus Smith J concluded that it would be "materially harder" to assess Mylan's losses (loss of the "first mover" advantage) than it would be to calculate the losses of Neurim and Flynn. $^{90}$

With respect to the fourth limb, the balance of convenience, Marcus Smith J made a number of points. Notably, with respect to the impact the notion of a generic manufacturer clearing the way to market has on the assessment of the adequacy of

\footnotetext{
83 Supra note 77, [28].

84 Supra note 77, [71]-[72].

85 Supra note 77, [74]-[81].

86 Supra note 77, [82]-[86].

87 Supra note 77, [74]-[81], particularly [81].

88 Supra note 77, [84].

89 Supra note 77, [85].

90 Supra note 77, [87]-[90], particularly [90].
} 
damages for them, the Judge stated that it is a relevant factor that should be taken into account. If a party puts themselves into a position where damages are an inadequate remedy because they have failed to take steps to clear the way that it could have sensibly taken then that must be considered. In this case, the Judge did note that Mylan could have taken the initiative to challenge the validity of the patent and the fact it did not do so was a relevant factor. However, as the Judge had already concluded that damages would be an adequate remedy for Neurim and Flynn, this factor did not change the outcome. Marcus Smith J refused the application for an interim injunction.

Note that since this judgment the High Court found the patent to be valid and infringed. $^{91}$

\section{Regeneron Pharmaceuticals Inc v. Kymab Ltd}

In the first patents judgment of the Supreme Court in $2020,^{92}$ the Supreme Court overturned the decision of the Court of Appeal in Regeneron Pharmaceuticals Inc $v$. Kymab $\mathrm{Ltd}^{93}$ holding two of Regeneron's patents covering transgenic antibodyproducing mice to be insufficient.

The Court of Appeal had held the patents to be sufficient. It was held that the teachings of the patents coupled with the common general knowledge were enough to enable a principle of general application which could be used to make all of the embodiments within a claim, even if, in fact, only some of the embodiments could be made at the priority date. ${ }^{94}$

The Supreme Court reversed this decision, with Lord Briggs giving the leading judgment (with whom Lord Reed, Lord Hodge, and Lord Sales agreed but with Lady Black dissenting). Lord Briggs concentrated his judgment on the fact that the relevant claim was a product claim to the mice and as such the case law requires the invention to be enabled across the whole range of products covered by the claim. ${ }^{95}$ The key question was "whether a product patent, the teaching of which enables the skilled person only to make some, but not all, of the types of product within the scope of the claim, passes the sufficiency test where the invention would contribute to the utility of all the products in the range, if and when they could be made". 96

Upon reflecting on the UK and EPO authorities on sufficiency, Lord Brigg stated that eight principles could be established:

\footnotetext{
${ }^{91}$ Neurim Pharmaceuticals (1991) Ltd v. Generics UK Ltd (t/a Mylan) [2020] EWHC 3270 (Pat), [2020] 12 WLUK 84.

92 Regeneron Pharmaceuticals Inc v. Kymab Ltd [2020] UKSC 27, [2020] Bus LR 1394; see this issue of IIC at https://doi.org/10.1007/s40319-021-01030-4.

93 [2018] EWCA Civ 671, [2018] 3 WLUK 685. See last year's patent review for a summary in IIC 51:341-361 (2020), https://doi.org/10.1007/s40319-020-00913-2.

${ }^{94}$ Ibid.

95 Supra note 92, [3], [5].

${ }^{96}$ Supra note 92, [5] per Lord Briggs.
} 
i) The requirement of sufficiency imposed by article 83 of the EPC exists to ensure that the extent of the monopoly conferred by the patent corresponds with the extent of the contribution which it makes to the art.

ii) In the case of a product claim, the contribution to the art is the ability of the skilled person to make the product itself, rather than (if different) the invention.

iii) Patentees are free to choose how widely to frame the range of products for which they claim protection. But they need to ensure that they make no broader claim than is enabled by their disclosure.

iv) The disclosure required of the patentee is such as will, coupled with the common general knowledge existing as at the priority date, be sufficient to enable the skilled person to make substantially all the types or embodiments of products within the scope of the claim. That is what, in the context of a product claim, enablement means.

v) A claim which seeks to protect products which cannot be made by the skilled person using the disclosure in the patent will, subject to de minimis or wholly irrelevant exceptions, be bound to exceed the contribution to the art made by the patent, measured as it must be at the priority date.

vi) This does not mean that the patentee has to demonstrate in the disclosure that every embodiment within the scope of the claim has been tried, tested and proved to have been enabled to be made. Patentees may rely, if they can, upon a principle of general application if it would appear reasonably likely to enable the whole range of products within the scope of the claim to be made. But they take the risk, if challenged, that the supposed general principle will be proved at trial not in fact to enable a significant, relevant, part of the claimed range to be made, as at the priority date.

vii) Nor will a claim which in substance passes the sufficiency test be defeated by dividing the product claim into a range denominated by some wholly irrelevant factor, such as the length of a mouse's tail. The requirement to show enablement across the whole scope of the claim applies only across a relevant range. Put broadly, the range will be relevant if it is denominated by reference to a variable which significantly affects the value or utility of the product in achieving the purpose for which it is to be made.

viii) Enablement across the scope of a product claim is not established merely by showing that all products within the relevant range will, if and when they can be made, deliver the same general benefit intended to be generated by the invention, regardless how valuable and groundbreaking that invention may prove to be. ${ }^{97}$

Lord Briggs went on to apply those principles to the case, concluding that the relevant claim "clearly" fails for insufficiency. ${ }^{98}$ Lord Briggs stated that at the

\footnotetext{
97 Supra note 92, [56].

98 Supra note 92, [57].
} 
priority date of the patents the disclosure of the patents and the common general knowledge did not enable all transgenic mice covered by the relevant claim to be "made". He concluded that it only enabled mice with a reverse chimeric locus containing a small part of the human variable region to be made. He stated, "[t]hus the claim to a monopoly over the whole of that range went far beyond the contribution which the product made to the art at the priority date, precisely because mice at the more valuable end of the range could not be made, using the disclosure in the patents." 99

Lord Briggs went on to note that comparing his eight principles (as set out above) with the principles applied by the Court of Appeal shows that the Court of Appeal did not correctly apply the law. ${ }^{100}$ Firstly, Lord Briggs stated that he did not accept the Court of Appeal's summary of the "essential patent bargain". He emphasised that with respect to product claims, the contribution to the art is the product which is enabled by the disclosure, and not the invention itself. He stated, "[p]atents are about products and processes, not pure ideas". ${ }^{101}$ Secondly, he did not accept the Court of Appeal's conclusion that an invention could be "enabled" in relation to a particular type of product within the scope of the claim even if the disclosure does not allow the skilled person to make it. He stated that the Court of Appeal "thought that it was enough that the benefits which the invention unlocked...would in due course be realised over the whole range, if and when all embodiments within the range could be made". But, he concluded that, that both Regeneron and Kymab could make a mouse with the whole human variable region "depends upon further (and different) inventions separately made by each of them some years after the priority date". 102

Lord Briggs further rejected that the Court of Appeal's approach was a "legitimate development of the law". He affirmed that the concept of sufficiency is "part of the bedrock" of patent law and essential for preventing patentees receiving a monopoly which outstrips their contribution to the art. ${ }^{103}$ He noted that to "water down" the sufficiency requirement would be to "tilt the careful balance" in favour of patentees in a way not envisaged by the European Patent Convention (EPC). He lastly noted that it may be that the Court of Appeal thought that the consequence of confining a patentee only to products which are enabled as at the priority date would be that they received "scant and short-lived reward for their efforts and ingenuity". However, he concluded that this should not be a relevant consideration and that what matters is "settled law". 104 The Supreme Court therefore allowed Kymab's appeal and reversed the decision of the Court of Appeal.

Despite this conclusion, Lady Black delivered a dissenting judgment. Lady Black expressed strong views that the patents should be sufficient. Lady Black highlighted the fact that Regeneron had not run its "mini-gene argument" (which argued that it

\footnotetext{
99 Ibid.

100 Supra note 92, [58].

101 Ibid.

102 Supra note 92, [58].

103 Supra note 92, [59].

104 Supra note 92, [60].
} 
was possible for a skilled team to have inserted part of the human variable region into the murine genome which would result in a transgenic mouse who could produce hybrid antibodies) at first instance. ${ }^{105}$ Thus, she concluded that the running of this argument at the Court of Appeal but not in the High Court necessarily meant that the Court of Appeal had a different starting point for the central legal issue. ${ }^{106}$ She noted that this argument was not contested before the Supreme Court and therefore the Supreme Court's starting point should have been the same as the Court of Appeal and not that of the High Court. ${ }^{107}$

Lady Black went on to state that "there is little, if any, real disagreement with the Court of Appeal's statement of legal principle" but it is in applying those principles where the majority of the Supreme Court diverge. ${ }^{108}$ She went on to conclude that she does not perceive the errors in approach taken by the Court of Appeal identified by the majority of the Supreme Court. She noted that it can be said that "the protection across the range coincides with the technical contribution of the patents which was to solve the problem of immunological sickness, or putting it (loosely) another way, to facilitate the making of immunologically efficient mice". As such, she concluded that she would not have overturned the Court of Appeal's decision. ${ }^{109}$

Despite Lady Black's dissenting opinion, the Supreme Court overturned the Court of Appeal's decision. In doing so, the Supreme Court has reasserted the legal position on sufficiency with respect to product claims and clarified that a patentee's claim must match the technical contribution made as at the priority date.

\section{Unwired Planet International Ltd v. Huawei Technologies (UK) Co Ltd}

In this long-awaited judgment, ${ }^{110}$ the Supreme Court decided on two appeals from the Court of Appeal concerning SEPs and FRAND: Unwired Planet International Ltd v. Huawei Technologies (UK) Co Ltd $;^{111}$ and Conversant Wireless Licensing SARL v. Huawei Technologies Co Ltd \& ZTE Corp. ${ }^{112}$ The Supreme Court dismissed the appeals from Huawei and ZTE and upheld the decisions of the courts below in a joint judgment from Lord Reed, Lord Hodge, Lady Black, Lord Briggs, and Lord Sales.

\footnotetext{
105 Regeneron Pharmaceuticals Inc v. Kymab Ltd [2016] EWHC 87 (Pat).

106 Supra note 92, [67]-[70].

107 Supra note 92, [70].

108 Supra note 92, [82].

109 Supra note 92, [86].

110 Unwired Planet International Ltd v. Huawei Technologies (UK) Co Ltd [2020] UKSC 37, [2020] Bus LR 2422, see IIC 51:1018-1019 (2020), doi:https://doi.org/10.1007/s40319-020-00984-1.

111 [2018] EWCA Civ 2344, [2018] 10 WLUK 355. For a summary of this decision see "United Kingdom Patent Decisions 2018" in IIC 50:331-351 (2019), doi:https://doi.org/10.1007/s40319-01900796-y.

112 [2019] EWCA Civ 38, [2019] 1 WLUK 278. See last year's patent review for a summary of this decision, IIC 51:341-361 (2020), doi:https://doi.org/10.1007/s40319-020-00913-2.
} 
The Supreme Court considered a number of issues raised on appeal:

i. Do the UK courts have the jurisdiction and may they exercise a power without agreement of both parties to: (a) grant an injunction to restrain the infringement of a UK patent where the patented invention is an essential component in an international standard of telecoms equipment marketed and sold worldwide, if the implementer of the invention does not enter into a global licence of a multinational patent portfolio; and (b) determine royalty rates and other disputed terms of such a global licence? ${ }^{113}$

ii. If the answer to i) is yes, is England the appropriate forum to determine these matters? (This forum non conveniens issue arose out of the Conversant appeal and was not raised by Huawei in the Unwired Planet appeal.) ${ }^{114}$

iii. What is the meaning and effect of the non-discrimination element of FRAND? Does it mean that the licence must be on the same terms as the licence previously entered into by Unwired Planet and Samsung? (From the Unwired Planet appeal.) ${ }^{115}$

iv. What is the proper interpretation of the CJEU's decision in Huawei $v$. $Z T E,{ }^{116}$ particularly, what is the nature of the guidance that a SEP-owner make a FRAND offer before commencing litigation? Should the court refuse to grant a SEP-owner an injunction on the ground it has breached EU competition law by failing to comply with the guidance set forth by the CJEU? (From the Unwired Planet appeal.) ${ }^{117}$

v. A more general question - in which circumstances is it appropriate for an English court to grant a prohibitory injunction or to award damages instead ${ }^{118}$

\section{Issue $i$. - jurisdiction to set a global licence?}

At first instance in Unwired Planet, Birss $\mathrm{J}$ (as he then was) had found that in a certain set of circumstances there would only be one set of terms that were deemed to be FRAND. And, in these circumstances, a global licence would be FRAND. The Judge also made a determination as to the royalty rates that would be FRAND in said global licence. Moreover, he also granted an injunction prohibiting Huawei from infringing Unwired Planet's UK patents that had been found to be valid and infringed. But, he stipulated that the injunction would not take effect if Huawei agreed to enter into a global licence on FRAND terms. ${ }^{119}$

\footnotetext{
113 Supra note 110, [50]-[91].

114 Supra note 110, [92]-[104].

115 Supra note 110, [104]-[127].

116 C-170/13 Huawei Technologies Co Ltd v. ZTE Corp, ZTE Deutschland GmbH [2015] OJ C 302, p. 2; see IIC 46:965-966 (2015), doi:https://doi.org/10.1007/s40319-015-0411-3.

117 Supra note 110, [128]-[158].

118 Supra note 110, [159]-[169].

119 Unwired Planet International Ltd v. Huawei Technologies Co Ltd [2017] EWHC 711 (Pat); [2017] 4 WLUK 74.
} 
Huawei appealed the first instance decision to the Court of Appeal challenging the global nature of the licence (as opposed to challenging the royalty rates that Birss J (as he then was) had set). The Court of Appeal followed Birss J's ruling, agreeing that a global licence was FRAND. It noted that global licensing was an industry norm and pointed to the impracticalities SEP-owners would face if they were to negotiate and seek to enforce licences on a country-by-country basis. The Court of Appeal, however, disagreed with the Judge with respect to his finding that there were only one set of terms that could be FRAND in any given circumstances. But, the Court of Appeal noted that this finding had no implication on the outcome of his decision. Thus, the Court of Appeal determined that if more than one set of licence terms was FRAND then it would be a matter of choice for the SEP owner as to which to offer. ${ }^{120}$

The Supreme Court agreed with the Court of Appeal, finding that the English courts have the power to grant an injunction with respect to UK patents if an implementer refuses to enter into a global licence on FRAND terms. ${ }^{121}$ It also held that the English courts have the power to determine those FRAND terms. ${ }^{122}$ The Supreme Court stated that although national courts determine questions of validity and infringement of national patents, the ETSI standard also empowers national courts to determine FRAND. Thus, the courts below had not made any determinations on the validity or infringement of foreign patents, rather, they had determined commercial practice. ${ }^{123}$ Crucially, an implementer would remain capable of challenging issues of validity and infringement of a national patent in national courts and could seek to change the royalty rates on the basis of those findings.

\section{Issue ii. - forum conveniens}

Two issues fell under this limb - (a) whether the High Court should have set aside service out of the jurisdiction on the two Chinese defendants (Huawei (China) and ZTE (China)) and permanently stayed the proceedings against the English defendants (Huawei (UK) and ZTE (UK)) on the grounds that China was the appropriate forum for the dispute; and (b) whether the claim for injunctive relief in the English proceedings should be temporarily stayed or case managed to allow the pending proceedings in China to conclude. ${ }^{124}$

As to (a), Huawei and ZTE both argued that the UK was a small market and therefore China was the appropriate forum for the dispute because they are both based there and that is where most of their sales were made. The Court of Appeal had addressed this issue by stating that the dispute before them was a claim for infringement of UK patents and an injunction in respect of that. Thus, because of the national nature of patents, such a dispute could not be heard in China. They held that

\footnotetext{
${ }_{120}$ Unwired Planet International Ltd v. Huawei Technologies Co Ltd [2018] EWCA Civ 2344; [2018] 10 WLUK 355.

121 Supra note 110, [63].

122 Supra note 110, [66]-[67].

123 Supra note 110, [58]-[63].

124 Supra note 110, [92].
} 
the determination of a global FRAND licence was part of the defence to the claim for an injunction with respect to UK patents. ${ }^{125}$

The Supreme Court also held that the UK is the more appropriate forum for the dispute. It did not follow the appellants characterisation of the dispute as one of form and substance about the terms of a global FRAND licence. Instead, it characterised the dispute as concerning the validity and infringement of UK patents, with the FRAND issues only arising as an aspect of the defence. ${ }^{126}$ However, the Supreme Court stated that even if the dispute had been characterised as concerning the terms of a global FRAND licence, part of a challenge to jurisdiction on forum conveniens grounds is to identify another forum that has jurisdiction to resolve the dispute. The Supreme Court held that such a forum had not been identified. It was held that it was not established that the Chinese courts actually have jurisdiction to determine the terms of a global FRAND licence (at least in the absence of agreement amongst the parties). ${ }^{127}$ The forum conveniens challenge failed.

\section{Issue iii. - characterisation of non-discriminatory element of FRAND}

This issue turned on whether non-discrimination could be characterised as being "hard-edged" (i.e. a SEP owner must offer licences on comparable terms to similar implementers) or "general" (i.e. a SEP owner must licence according to market situation as exists at the time of licensing thus allowing for lower rates to be agreed with licensees who agree to licence earlier). Both Birss $\mathbf{J}$ at first instance and the Court of Appeal had found that the non-discrimination element could not be characterised as "hard-edged".

The Supreme Court agreed with the courts below that on a proper construction of the relevant clause in ETSI's IPR Policy, the non-discrimination element was "general" rather than "hard-edged". ${ }^{128}$ It went on to determine, though, that the obligation that licences should be available on FRAND terms is "a single unitary obligation". It further stated, "[1]icence terms should be made available which are 'fair, reasonable and non-discriminatory', reading that phrase as a composite whole". ${ }^{129}$ As such, this indicates that "the terms and conditions on offer should be such as are generally available as a fair market price for any market participant, to reflect the true value of the SEPs to which the licence relates and without adjustment depending on the individual characteristics of a particular market participant. Put another way, there is to be a single royalty price list available to all". ${ }^{130}$

The Supreme Court further noted that it was "[a] powerful indication" that the non-discrimination element was general and not "hard-edged" that ETSI had considered by rejecting the inclusion of "most favourable licence" clause in the

\footnotetext{
125 Conversant Wireless Licensing S.A.R.L. v. Huawei Technologies Co Ltd [2019] EWCA Civ 38; [2019] 1 WLUK 278.

126 Supra note 110, [95].

127 Supra note 110, [96]-[97].

128 Supra note 110, [112]-[116].

129 Supra note 110, [113].

130 Supra note 110, [114].
} 
undertaking. It stated that to include a "hard-edged" non-discrimination obligation would be to introduce a "most favourable licence" term "by the back door". ${ }^{131}$

Issue iv. - competition law and Huawei v. ZTE

Unwired Planet had commenced the litigation before following the steps outlined by the CJEU in Huawei v. ZTE. ${ }^{132}$ As such, Huawei argued that this meant Unwired Planet was not entitled to an injunction. At first instance, Birss $\mathbf{J}$ had found that Huawei v. $Z T E^{133}$ operates as a safe harbour from competition law abuse for those who follow the steps set out therein. It does not, however, necessarily mean that those who do not follow the steps are behaving in an abusive manner. The Court of Appeal followed Birss J's finding. The Supreme Court also followed the findings below. ${ }^{134}$

The Supreme Court rejected the argument that Unwired Planet had acted abusively by not following the steps in Huawei $v . Z^{135}$ prior to commencing litigation. It held that the nature and notice required as set out by the CJEU depends upon the facts of the case in hand. It held that Unwired Planet had shown that it was willing to grant SEP licences on FRAND terms as determined by the court and therefore this was sufficient to illustrate that it is a willing licensor. ${ }^{136}$

Issue v. - jurisdiction to grant a prohibitory injunction

The appellants finally argued that the courts should not have granted a prohibitory injunction but instead should have awarded damages based on royalties due with respect to the UK patents. ${ }^{137}$ The Supreme Court held that there was not "any basis on which this court could properly substitute an award of damages for the injunction...". ${ }^{138}$ It went on to say that an award of damages would be unlikely to be an adequate substitute for what would be lost by not granting the injunction. ${ }^{139}$ It noted that the nature of setting standards for technology products is so they can operate on a global basis. It stated, "[o]nce the patents have been accepted as SEPs, it may well be impractical for the patent-holder to bring proceedings to enforce its rights against an infringing implementer in every country where the patents have been infringed" because the cost would be prohibitively high. ${ }^{140}$ Therefore, it continued, implementers who were infringing SEPs would have an incentive to continue infringing them until they were compelled to pay royalties on a countryby-country basis. ${ }^{141}$

As such, Huawei and ZTE's appeals were dismissed and the decisions below were upheld. This decision was much anticipated both in the UK and globally. It

\footnotetext{
131 Supra note 110, [116].

132 Supra note 116.

133 Supra note 116.

134 Supra note 110, [149] et seq.

135 Supra note 116.

136 Supra note 110, [158].

137 Supra note 110, [159] et seq.

138 Supra note 110, [163].

139 Supra note 110, [166].

140 Ibid.

141 Supra note 110, [167].
} 
places the UK courts at the forefront of the evolving landscape concerning FRAND disputes. This decision provides clarity on the UK position. UK courts can and are willing to determine the terms of global FRAND licences and are prepared to grant injunctions to prevent infringement of UK SEPs if infringers do not enter into global licences on FRAND terms. We watch this space to see just how this decision will impact how FRAND litigation plays out in the future.

Open Access This article is licensed under a Creative Commons Attribution 4.0 International License, which permits use, sharing, adaptation, distribution and reproduction in any medium or format, as long as you give appropriate credit to the original author(s) and the source, provide a link to the Creative Commons licence, and indicate if changes were made. The images or other third party material in this article are included in the article's Creative Commons licence, unless indicated otherwise in a credit line to the material. If material is not included in the article's Creative Commons licence and your intended use is not permitted by statutory regulation or exceeds the permitted use, you will need to obtain permission directly from the copyright holder. To view a copy of this licence, visit http:// creativecommons.org/licenses/by/4.0/.

Publisher's Note Springer Nature remains neutral with regard to jurisdictional claims in published maps and institutional affiliations. 